\title{
Evaluation of Cytotoxicity of Gossypium barbadense L. Extract in Bone Cord Cells through the Micronucleus Test
}

\author{
Thiago Dornelas de Oliveira ${ }^{1}$, Joice Meire Rodrigues, ${ }^{1,2}$, Thiago Sande Miguel ${ }^{3}$, \\ Nayrton Kalys Cruz dos Anjos 3 , Juscélio Clemente de Abreu ${ }^{4,5}$, \\ Lamara Laguardia Valente Rocha ${ }^{4,6}$, Raquel Xavier Ligeiro Dias ${ }^{4,7}$, \\ Daniel Almeida da Costa ${ }^{8}$
}

\footnotetext{
${ }^{1}$ Academic of the Graduate Course in Medicine of the University Center of Caratinga, Caratinga, Brazil

${ }^{2}$ Religious Sciences from the Pontifical Catholic University of Sao Paulo, São Paulo, Brazil

${ }^{3}$ The Medical School at the Center of Higher Education of Valença, Valença, Brazil

${ }^{4}$ The Institute of Health Sciences of the University Center of Caratinga, Caratinga, Brazil

${ }^{5}$ Federal University of Lavras, Lavras, Brazil

${ }^{6}$ Federal University of Viçosa, Viçosa, Brazil

${ }^{7}$ Department of Biochemistry and Molecular Biology at the Federal University of Viçosa, Viçosa, Brazil

${ }^{8}$ Faculty of Medicine of Valença, Valença, Brazil

Email: raquelligeiro@yahoo.com.br, professordanielfmv@gmail.com
}

How to cite this paper: de Oliveira, T.D., Rodrigues, J.M., Miguel, T.S., dos Anjos, N.K.C., de Abreu, J.C., Rocha, L.L.V., Dias, R.X.L. and da Costa, D.A. (2017) Evaluation of Cytotoxicity of Gossypium barbadense L. Extract in Bone Cord Cells through the Micronucleus Test. Journal of Biosciences and Medicines, 5, 84-91. https://doi.org/10.4236/jbm.2017.57008

Received: June 13, 2017

Accepted: July 25, 2017

Published: July 28, 2017

Copyright $\odot 2017$ by authors and Scientific Research Publishing Inc. This work is licensed under the Creative Commons Attribution International License (CC BY 4.0).

http://creativecommons.org/licenses/by/4.0/ c) (i) Open Access

\begin{abstract}
The cotton plant is a plant belonging to the family Malvaceae and its leaves are often used in folk medicine. The present study aimed to evaluate the mutagenic or antimutagenic activity of the ethanolic extract of Gossypium barbadense L. (EEG) and to analyze its capacity to prevent or repair mutagenic lesions caused by cyclophosphamide (CP). For the Micronucleus test, Swiss mice were divided into 5 groups: negative control; Positive control: treated with $50 \mathrm{mg} / \mathrm{kg}$ cyclophosphamide (CP), group receiving EEG $500 \mathrm{mg} / \mathrm{kg}$ for 7 days; Group receiving EEG $500 \mathrm{mg} / \mathrm{kg}$ for 7 days associated with CP24h before euthanasia; Group who received CP and EEG $500 \mathrm{mg} / \mathrm{kg}$ for 7 days. After the treatment period, the animals were euthanized, the bone marrow removed and the blood smear prepared. From this analysis, it was observed that the EEG caused a significant increase in the number of micronucleated erythrocytes, indicating mutagenic activity of the extract. In addition, it was verified that the extract did not present the capacity to prevent, but it presented the capacity of repair of the chromosomal damages caused by CP.
\end{abstract}

\section{Keywords}

Gossypium, Mutagenesis, Phytotherapy 


\section{Introduction}

The use of natural resources as a source for solving health problems has been a common practice since the emergence of human communities. In this context, several plant species have been used for therapeutic purposes, thus constituting Traditional Medicine [1].

The cotton is a plant belonging to the genus Gossypium and the family Malvaceae [2]. In Brazil three species belonging to the genus Gossypium are found, among them is Gossypium barbadense L., a perennial tree species originating in the southern region of Ecuador and North of Peru [3]. Currently, this species can be found in almost all Brazilian territory. Although it is not a Brazilian plant, Brazil is considered a major secondary [4].

The leaves of cotton (Gossypium barbadense L.) are often used in folk medicine as uterotonic, menstrual regulator, anti-hemorrhagic, uterine anti-inflammatory, earaches, fever, strokes and pain in the body. Generally, the leaves are prepared as tea or juice and administered to the patient according to the empirical knowledge of the population [5] [6].

The therapeutic efficacy of medicinal plants is recognized both by the World Health Organization (WHO) and by pharmaceutical laboratories [1]. Thus, they are considered to be an indisputable source of bioactive compounds with therapeutic potential and as a viable alternative for the development of safe and effective [7].

Brazil is the most genetically diverse country in the world and represents an important source of pharmacologically active compounds on the planet. The plant extracts obtained from these plants are known for their effectiveness against various types of cancer. In addition, it is estimated that $60 \%$ of antitumor drugs are of plant origin [8].

Cancer is a public health problem and consists of a neoplastic cell alteration that occurs from mutations in the genetic material (DNA) of a cell, causing it to proliferate in disorder and invade tecidos and organs quickly [9]. The search for chemicals capable of disrupting this disordered cell cycle could lead to cancer cure. Therefore, several natural chemicals are often genetically tested [10].

On the other hand, in spite of the beneficial effects of medicinal plants, it is noticed that it insists on remaining in the population an erroneous thought of the non-existence of toxicity in herbal products, since they are of natural origin. However, it is now known that medicinal plants can hide a huge risk to the health of the population, evidencing the need to develop more accurate research that guarantees greater quality and safety to consumers [11].

The Micronucleus Test is a cytogenetic test widely used in the detection of clastogenic and aneugenic agents. Clothogenic agents are those that induce structural changes in the chromosomes, while the aneugenic induce numerical chromosomal alterations. Micronuclei are identified in any type of cell, and can be evaluated in the diagnosis of hematological diseases, urinary tract and also in rodent and plant tests [12] [13].

This study aimed to evaluate the mutagenic or antimutagenic activity of Gos- 
sypium barbadense L. leaves in bone marrow cells of Swiss mice for a seven day experimental period. In this way, it will be possible to estimate the risk to which the population is exposed when preparing teas with cotton leaves for therapeutic purposes and consume indiscriminately without knowing the mutagenic potential of the plant species in question.

\section{Material and Methods}

\subsection{Study Design and Micronucleus Test}

First, to obtain the extract, dried leaves (100 g) of Gossypium barbadense L. were crushed and extracted with ethanol by the maceration method, using a 70\% (v/v) hydroalcoholic mixture. The material was filtered and concentrated on a rotary evaporator under reduced pressure, at a temperature of up to $50^{\circ} \mathrm{C}$, to the final volume of $100 \mathrm{~mL}$ to give the crude ethanolic extract of Gossypium barbadense L. (EEG).

The micronucleus test was performed as described by Adler and Attia [14]. Thus, young Swiss male mice were obtained from the breeding room of the Federal University of Minas Gerais, with approximately $34 \mathrm{~g}$. The animals were kept in plastic boxes, receiving water and feed Commercial ad libitum. These were divided into five groups of six animals each.

Group A represents the negative control, without receiving special treatment. Group B represents the positive control, being treated with $50 \mathrm{mg} / \mathrm{kg}$ of cyclophosphamide (CP) intraperitoneally 24 hours before euthanasia. Group C received extract ethanol from Gossypium barbadense L. (500 mg/kg) for 7 days. Group D received extract ethanol from Gossypium barbadense L. (500 mg/kg) for 7 days and CP $(50 \mathrm{mg} / \mathrm{kg})$, intraperitoneally, 24 hours before euthanasia. Group E received CP $(50 \mathrm{mg} / \mathrm{kg})$ on the first day and the ethanolic extract of Gossypium barbadense L. (500 mg/kg) during the next 7 days.

The vegetable extract was administered orally, via esophageal gavage, once daily for 7 days. After the treatment period, the right posterior femoral femur was removed, cleaned and the epiphyses cut off. The bone marrow was removed by inserting into the spinal canal the needle of a syringe with $2.5 \mathrm{~mL}$ of fetal bovine serum. The samples were centrifuged at $1000 \mathrm{rpm}$ for $5 \mathrm{~m}$. The supernatant was discarded and the precipitate dissolved in brine. Next, the smear on the blade, stained with Giemsa, was taken. 1000 cells were analyzed per animal, determining the frequency of micronucleated erythrocytes (NME).

\subsection{Systematization and Data Analysis}

For statistical analysis, the means of the parameters studied were compared between the groups using the statistical analysis of variance (ANOVA) and Tukey test. The STATISTICA 3.11 software was used, being $\mathrm{p}<0.05$, considered significant. In the data was used the transformation of square root of $\mathrm{X}$ for the statistical analysis, since the data was obtained by counting. The results were expressed as mean and standard deviation. 


\subsection{Ethical Considerations}

This work was forwarded and approved by the Commission of Ethics in the Use of Animals of the University Center of Caratinga - MG (CEUA - UNEC).

\section{Results}

The data obtained during the investigation of the mutagenic potential of the EEG are shown in Figure 1. As expected, the data confirm the mutagenic potential of cyclophosphamide proven in the literature by a significant increase in the frequency of micronuclei $(11 \pm 1.75)$ when compared to Negative control group without exposure $(2 \pm 1.17)$. Similarly, the exposure of the mice to the EEG also showed a significant increase in the frequency of micronuclei $(7 \pm 1.33)$, suggesting a mutagenic potential to the extract (Figure 2).

To evaluate the protective activity of DNA, the results between the EEG treatments for seven days followed by cyclophosphamide $(2.97 \pm 0.49)$ and the other groups (Cyclophosphamide (3.36 \pm 0.26$)$, extract $(2.60 \pm 0.25)$ and cyclophosphamide followed by seven days of EEG treatment $(2.56 \pm 0.37)$, with no statistically significant difference between them ( $p>0.05$, ANOVA, Tukey).

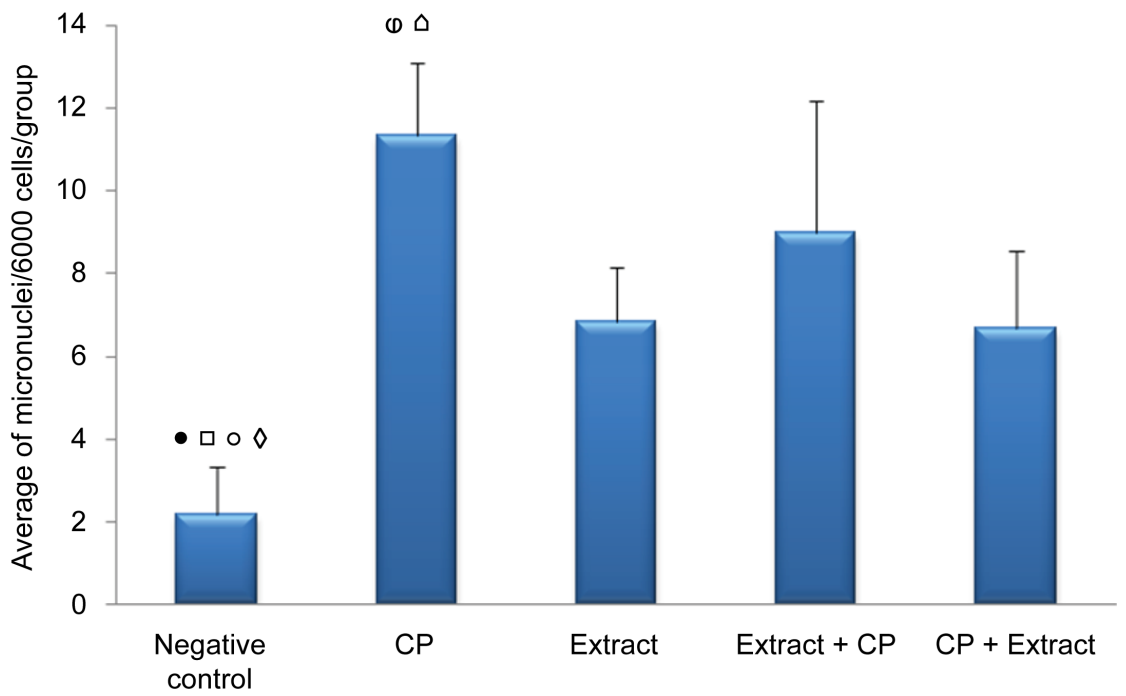

Figure 1. Average Micronucleus in erythrocytes (6000 cells/group) of mice ( $n=6 /$ group) exposed to treatment with ethanolic extract of Gossypium barbadense L. (EEG) for 7 days. The relative standard deviation was calculated based on the mean micronuclei per group. The positive control group received a single dose of cyclophosphamide (CP) (50 $\mathrm{mg} / \mathrm{kg} /$ day). The negative control group received no treatment. One group received EEG for 7 days and CP 24 hours before euthanasia and the other group received CP on the first day and EEG for 7 days. ANOVA, Tukey's test. $\bullet$ Significant difference between Negative control $\times \mathrm{CP}$ (Analysis of significant variance $(\mathrm{Q}=1.93$ and $\mathrm{p}<0.01)$ ); $\square$ Significant difference between Negative control $\times$ Extract (Analysis of significant variance $(Q=1.18$ and $\mathrm{p}<0.01)$ ); $\circ$ Significant difference between Negative control $\times$ Extract $+\mathrm{CP}$ (Analysis of significant variance $(\mathrm{Q}=1.54$ and $\mathrm{p}<0.01)) ; \diamond$ Significant difference between Negative control $\times \mathrm{CP}+$ Extract (Analysis of significant variance $(\mathrm{Q}=1.13$ and $\mathrm{p}<0.01)$ ); $\oplus$ Significant difference between $\mathrm{CP} \times$ Extract (Analysis of significant variance $(\mathrm{Q}=0.75$ and $\mathrm{p}<0.05)$ ). $\triangle$ Significant difference between $\mathrm{CP} \times \mathrm{CP}+$ Extract (Analysis of significant variance $(\mathrm{Q}=0.80$ and $\mathrm{p}<0.01))$. 


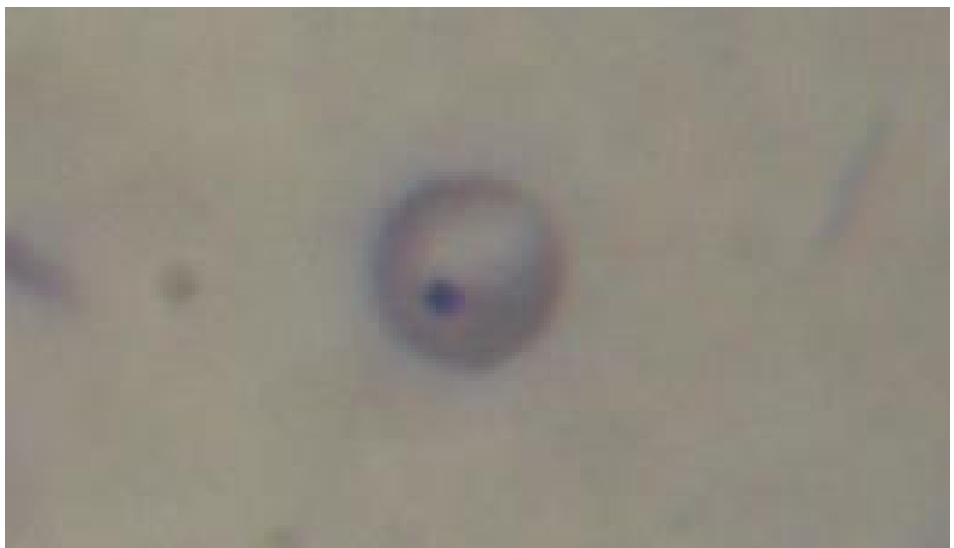

Figure 2. Photomicrograph indicating the micronucleus formation (arrow) in erythrocyte of swiss mice exposed to the ethanolic extract of Gossypium barbadense L. (500 mg/kg), orally, for 7 days, 100×.

These data suggest that EEG does not have the ability to protect DNA from bone marrow cells against clastogenic agents.

However, comparing the results of the treatments performed with cyclophosphamide followed by seven days of treatment with EEG $(2.56 \pm 0.37)$ and the positive control $(3.36 \pm 0.26)$, it was possible to identify a statistically significant result among them ( $\mathrm{p}<0.01$, ANOVA, Tukey's test), indicating possible anticlastogenic effect of the extract.

\section{Discussion}

Considering the results found in this study, the EEG treatment evidenced a significant increase of micronucleated erythrocytes in the bone marrow of Swiss mice, suggesting the presence of cytotoxic and genotoxic extract activity. This finding is consistent with Meira-Neto and Almeida [15] who carried out a bioassay of cytotoxicity in an ethanol-cotton leaf extract (Gossypium arboreum L.) showing that the extract shows moderate toxicity.

According to a study by Mans et al. [16], which evaluated the effect of plant extracts on the proliferation and formation of DNA damage in Chinese hamster ovary cells, EEG inhibited cell growth and caused appreciable damage to nearby DNA To $40 \%$. In addition, according to Thomas, et al. [17], intraperitoneal injection of EEG in male rats demonstrated that the cotton contains substances capable of rapidly inducing lesions in cells of the testis, liver, kidneys and muscle tissues.

On the other hand, Melo [18] demonstrated that the consumption of cottonseed by sheep in concentrations of $15 \%, 30 \%$ and $45 \%$ for 42 days did not present significant changes in the frequency of micronucleated erythrocytes in the respective study.

The mutagenic activity attributed to the EEG in this study can be justified by the phytochemical composition of the extract, which includes gossypol, toxic alkaloid polyphenolic, which shows toxicity in its free form [19]. According to Nayak and Buttar [20], the potential of gossypol to damage chromosomes was 
evaluated in cytogenetic studies and the results suggest that this molecule has potentially mutagenic and clastogenic activity in cells of the bone marrow of mice.

However, some in vivo and in vitro studies have revealed antitumor properties of gossypol in many cytosolic and mitochondrial enzyme systems that are critical for the growth of tumor cells, including melanoma, endometrial, colon, lung, prostate, breast, brain and adrenocortical cancer cells [21] [22] [23].

In the present study, the EEG did not show activity of protection of chromosomes of bone marrow cells against clastogenic agents. However, the anticlastogenic effect could be evidenced in the extract, justifying the presence of phytochemical constituents that through a variety of mechanisms can repair DNA, such as inhibition of genotoxic effects, signal transduction, antioxidant activity or elimination of free radicals [24] [25] [26].

According to Wang et al., [27] gossypol extracted from the species Gossypium barbadense $\mathrm{L}$. presented a relative ability to prevent DNA damage due to its antioxidant potential. Thus, suggesting that the protective activity of DNA would be related to the extinction of free radicals of the medium, relieving the cellular extresseoxidative. Other findings from this study demonstrate the ability of gossypol to inhibit the growth of Trypanosoma brucei cells in the growth of cervical, breast and colon cancer cells, enhancing the anticlastogenic effect evidenced in the present study.

\section{Conclusion}

The results showed that the EEG shows cytotoxic and genotoxic activity in the cells of the bone marrow of mice. This was evidenced by the significant increase of micronucleated erythrocytes detected by the Micronucleus test. These data suggest that the indiscriminate EEG consumption by the population may represent a risk to human health by increasing the frequency of genetic mutations and consequently predisposing to cancer. In addition, it was verified that the extract did not present the capacity to prevent but presented the capacity of repair of the chromosomal damages caused by the CP. This indicates low EEG potential in the prevention of genetic mutations, but opens new horizons in the search for agents capable of repairing genetic damages. The shortage of studies that deal with the effects of the extract of Gossypium barbadense L., mainly considering the bone marrow made it difficult to discuss the results found in this research. In view of the findings reported here, it is suggested to carry out further studies aiming at the phytochemical characterization of the cotton leaf extract in order to identify all the constituents and their respective biological effects.

\section{Acknowledgements}

To all who contributed directly or indirectly to the conclusion of this work.

\section{References}

[1] Rocha, F.A.G., Araújo, L.S.G., Lima, T.G.D., Silva, E.R., Silva, P.A., Gundim, 
M.K.M., Araújo, M.F.F. and Costa, N.D.L. (2013) Characteristics of the Informal Trade of Medicinal Plants in the Municipality of Lagoa Nova/RN. Holos, 5, 264281. https://doi.org/10.15628/holos.2013.1344

[2] Joly, A.B. (2002) Botany: Introduction to Plant Taxonomy. 13th Edition, Companhia Editora Nacional, São Paulo.

[3] Brubaker, C.L., Bourland, F.M. and Wendel, J.F. (1999) The Origin and Domestication of Cotton. In: Smith, C.W. and Cothen, J.T., Eds., Cotton: Origin, History, Technology and Production. Johnston and Sounds, New York, 23-32.

[4] Almeida, V.C., Pereira, G.S., Moura, M.A., Silva, R.A., Barroso, P.A.V., Hoffmann, L.V., Andrade, F.P. and Lamas, F.M. (2009) In Situ Characterization and Conservation of Germplasm of Gossypium barbadense L. (Malvaceae) in the State of Mato Grosso do Sul. In: Brazilian Cotton Congress, Foz do Iguaçu. Sustainability of Brazilian Cotton Growing and Expansion of Markets: Annals. Embrapa Cotton, Campina Grande.

[5] Borges, K.N., Noblick, L.R. and Lemos, M.J.S. (1986) Contribution to the Study of the Medicinal Flora of the Feira de Santana Micro-Region (BA). Sitientibus, 3, 101116.

[6] Coelho, L.A., Silva, S.L.C. and Macedo, G.E.L. (2010) Ethnobotanical Survey in the Community of Rio Preto do Criciúma, in the municipality of Jequié-BA: A Preliminary Analysis. Encyclopedia Biosphere, 6, 1-17.

[7] Simon (2013) Chemical Composition, Efficacy and Toxicity of Medicinal Plants Used in the Treatment of Obesity. Thesis, Federal University of Lavras, Lavras.

[8] Pais, V.A.A. (2011) Evaluation of In Vitro and In Vivo Anticancer Activity of Medicinal Plants from Serra da Mantiqueira Paulista. Dissertation, Federal University of Campinas, Campinas.

[9] INCA. National Cancer Institute. http://www.inca.gov.br/conteudo_view.asp?id=322

[10] Silva, A.A. and Bohm, F.M.L.Z. (2012) Studies of the Effects of Agaricusblazei Tea (Sun Mushroom) on Mitotic Index of Allium Cepa (Onion) Meristematic Cells. Dialogues \& Knowledge, 8, 25-39.

[11] Rodrigues, H.G., Meireles, C.G., Lima, J.T.S., Toledo, G.P., Cardoso, J.L. and Gomes, S.L. (2011) Embryotoxic, Teratogenic and Abortive Effect of Medicinal Plants. Revista Brasileira de Plantas Medicinais, 13, 359-366.

[12] Gonçalves, C.D.P. (2012) Evaluation of the Genotoxic Damage to the DNA of Mice Exposed to Vegetables Grown on Controlled Deposits of Coal Tailings. Monograph, Faculty of Pharmacy of the University of Extremo Sul Catarinense, Crisciúma.

[13] Fão, F., Zan, R.A., Brondani, F.M.M., Ramos, L.J. and Meneguetti, D.U.O. (2012) Analysis of the Mutagenic Potential of the Sap of the Crotonlechleri Bark (Müll. Arg), in the State of Rondônia, Western Amazonia. SaBios-Revista de Saúde e Biologia, 7, 91-98.

[14] Adler, I.D. and Attia, S.M. (2003) Nicotine Is Not Clastogenic at Doses of 1 or 2 $\mathrm{mg} / \mathrm{kg}$ Body Weight Given Orally to Male Mice. Mutation Research/Genetic Toxicology and Environmental Mutagenesis, 542, 139-142. https://doi.org/10.1016/j.mrgentox.2003.08.008

[15] Meira-Neto, R.A. and Almeida, S.S. (2015) Phytochemical, Microbiological and Cytotoxic Evaluation of Leaves of Gossypium arboreum L. (Malvaceae). Biota Amazônia, 5, 18-22. https://doi.org/10.18561/2179-5746/biotaamazonia.v5n2p18-22

[16] Mans, D.R.A., Tjoe, L.J.D., Oedayraisingh, K., Soekhoe, R., Magali, I., Friperson, P., Djotaroeno, M., Pawirodihardjo, J., Toelsie, J.R., Hasrat, J.A. and Bipat, R. (2015) 
Cytotoxic and Genotoxic Effects of Commonly Used Surinamese Medicinal Plants in Cultured Chinese Hamster Ovary Cells. 60 th Annual Scientific Meeting, Caribbean Public Health Agency, Grenada, Caribbean Public Health Agency, The University of the West Indies, Faculty of Medical Sciences, 1-75.

[17] Thomas, K.D., Caxton-Martins, A.E., Elujoba, A.A. and Oyelola, O.O. (1991) Effects of an Aqueous Extract of Cotton Seed (Gossypium barbadense L.) on Adult Male Rats. Advances in Contraception, 7, 353-362. https://doi.org/10.1007/BF02340182

[18] Melo, F.B.A. (2014) Nutrient Intake, Performance and Genotoxic Analysis of Sheep Fed with Inclusion of Cotton Pie in the Diet. Dissertation, Federal Rural University of the Semi-Arid, Mossoró.

[19] Romero, A.C., Mariano, I.C., Uliana, R., Louvandini, H. and Abdalla, A.L. (2011) Implicações para exatidão na quantificação do gossipol livre: II. Variabilidade associada à extração e efeito do tempo de maceração. Revista de Educação Continuada em Medicina Veterinária e Zootecnia do CRMV-SP, 9, 71.

[20] Nayak, B.N. and Buttar, H.S. (1986) Induction of Sister Chromatid Exchanges and Chromosome Damage by Gossypol in Bone Marrow Cells of Mice. Teratogenesis, Carcinogenesis, and Mutagenesis, 6, 83-91. https://doi.org/10.1002/tcm.1770060202

[21] Gilbert, N.E., Reilly, J.E., Chang, C.J., Lin, Y.C. and Brueggemeier, R.W. (1995) Antiproliferative Activity of Gossypol and Gossypolone on Human Breast Cancer Cells. Life Sciences, 57, 61-67. https://doi.org/10.1016/0024-3205(95)00243-Y

[22] Liang, X.S., Rogers, A.J., Webber, C.L., Ormsby, T.J., Tiritan, M.E., Maltin, S.A., et al. (1995) Developing the Gossypol Derivatives with Enhanced Antitumor Activity. Investigational New Drugs, 13, 181-186. https://doi.org/10.1007/BF00873798

[23] Wu, D. (1989) An Overview of the Clinical Pharmacology and Therapeutic Potential of Gossypol as a Male Contraceptive Agent and in Gynecological Disease. Drugs, 38, 333-341. https://doi.org/10.2165/00003495-198938030-00001

[24] Hartman, P.E. and Shankel, D.M. (1990) Antimutagens and Anticarcinogens: A Survey of Putative Interceptor Molecules. Environmental and Molecular Mutagenesis, 15, 145-182. https://doi.org/10.1002/em.2850150305

[25] De Flora, S., Bagnosco, M. and Vainio, H. (1999) Modulation of Genotoxic and Related Effects b Carotenoids and Vitamin A in Experimental Models: Mechanistic Issues. Mutagenesis, 14, 153-172. https://doi.org/10.1093/mutage/14.2.153

[26] Mantle, D., Lennard, T.W. and Pickering, A.T. (2000) Therapeutic Applications of Medicinal Plants in the Treatment of Breast Cancer: A Review of Their Pharmacology, Efficacy and Tolerability. Adverse Drug Reactions and Toxicology Reviews, 19, 223-240.

[27] Wang, X., Beckham, T.H., Morris, J.C., Chen, F. and Gangemi, J.D. (2008) Bioactivities of Gossypol, 6-Methoxygossypol, and 6,6'-Dimethoxygossypol. Journal of Agricultural and Food Chemistry, 56, 4393-4398. https://doi.org/10.1021/jf073297u 
Submit or recommend next manuscript to SCIRP and we will provide best service for you:

Accepting pre-submission inquiries through Email, Facebook, LinkedIn, Twitter, etc. A wide selection of journals (inclusive of 9 subjects, more than 200 journals)

Providing 24-hour high-quality service

User-friendly online submission system

Fair and swift peer-review system

Efficient typesetting and proofreading procedure

Display of the result of downloads and visits, as well as the number of cited articles Maximum dissemination of your research work

Submit your manuscript at: http://papersubmission.scirp.org/

Or contact jbm@scirp.org 